April 2012

\title{
Around the "G" Word: From Raphael Lemkin's Definition to Current Memorial and Academic Controversies
}

Jacques Semelin

Follow this and additional works at: https://digitalcommons.usf.edu/gsp

\section{Recommended Citation}

Semelin, Jacques (2012) "Around the "G" Word: From Raphael Lemkin's Definition to Current Memorial and Academic Controversies," Genocide Studies and Prevention: An International Journal: Vol. 7: Iss. 1: Article 5.

Available at: https://digitalcommons.usf.edu/gsp/vol7/iss1/5

This Articles is brought to you for free and open access by the Open Access Journals at Digital Commons @ University of South Florida. It has been accepted for inclusion in Genocide Studies and Prevention: An International Journal by an authorized editor of Digital Commons @ University of South Florida. For more information, please contact digitalcommons@usf.edu. 


\title{
Around the "G" Word: From Raphael Lemkin's Definition to Current Memorial and Academic Controversies
}

\author{
Jacques Semelin \\ Center for International Research and Studies-CNRS-Sciences Po, Paris
}

\begin{abstract}
The term "genocide" has generated passion and misunderstanding since its coining in 1944 by Raphael Lemkin. Applying this term to very heterogeneous historical and current situations brings up many objections and debates. The first problem arising from the word genocide concerns its uses, including its memorial, humanitarian, legal, and political purposes. Scholars are divided about its meaning. However, this article stresses that the global digital academic enterprise, Online Encyclopedia of Mass Violence, represents today a unique effort to gather the most important historical cases of mass human destruction, with respect to their own singularity, while offering a way to compare them according to the same framework of analysis. It builds a strong body of knowledge and follows a rigorous methodology, including a peer-review process. This article also brings some clarifications to three questions: the relationship of genocide studies with international law, the strong tendency in this field to qualify any massacre as genocide, and the legal relevance of the notion of crime against humanity.
\end{abstract}

Key words: genocide, massacre, mass violence, crime against humanity

In this short article, I restate what has been my general approach regarding the definition of genocide over the past decade. I also try to explain why I have become more flexible about its definition, particularly in light of my experience with the global publication Online Encyclopedia of Mass Violence (OEMV) which was founded in 2004. ${ }^{1}$ This project was initiated in 2004 by Sciences Po Paris (Center for International Research Studies). It has taken us nearly four years to get the OEMV ready to be put online. Considering the highly sensitive nature of this project and the relative novelty of this field of research, this maturation period has proved valuable. The gradual construction of this Web site is the result of genuine teamwork on the part of computer specialists and researchers, who endeavored to coordinate technical, scientific, and ethical criteria.

There's no doubt that the term "genocide" has generated passion and misunderstanding since its creation. Indeed, since the United Nations adopted the Convention on the Prevention and Punishment of the Crime of Genocide (UNCG) on 9 December $1948,{ }^{2}$ genocide has come to mean absolute evil: mass atrocities against defenseless civilians. Coined in 1944 by the Polish jurist Raphael Lemkin, the term has gained increasing international acceptance. Thus, one has talked about genocide in almost every major deadly conflict of the second half of the twentieth century from Cambodia to Darfur, including Burundi, Rwanda, Guatemala, Colombia, Iraq, Bosnia, Chechnya, Argentina, and Ethiopia.

The term has also been used retrospectively to qualify the massacre of the inhabitants of Melos by the Greeks (fifth century BCE), the Vendée people in 1793 by the French revolutionary army, the native people in North America, and the Armenians in

Jacques Semelin, "Around the 'G' Word: From Raphael Lemkin's Definition to Current Memorial and Academic Controversies," Genocide Studies and Prevention 7, 1 (April 2012): 24-29. (c) 2012 Genocide Studies and Prevention. doi: 10.3138/gsp.7.1.24 
1915 as well as the cases of famine in Ukraine, the various deportations of populations by Stalin, and of course, the extermination of European Jews and Roma. It has even been applied to the US nuclear bombings of Hiroshima and Nagasaki. This list is by no means exhaustive.

Applying this "genocide" notion to these very heterogeneous historical situations has generated many objections and passionate debates. These numerous handlings of the concept suggest the need to resort to a word of universal significance to point out a major phenomenon in the twentieth century-that of the mass destruction of civilian populations. Other terms have, in fact, been suggested, such as "politicide" proposed by Barbara Harff and Ted Gurr and "democide" proposed by Rudolph Rummel. ${ }^{3}$ But these alternative notions have no legal recognition and thus the word genocide continues to dominate the field.

The first problem arising from the word genocide has to do with its various uses. It has a role in various kinds of political, identity-driven, or humanitarian rhetoric. This is a full-fledged matter of research and its several uses reveal some issues of great significance. I have tried to identify the main ones.

Issues of memory. When a population has been killed on a mass scale, the survival community sometimes struggles to have this past suffering recognized as genocide. The most emblematic fight in this field is that of the Armenian community in the face of aggressive denial by the Turkish government and its supporters around the world. But there are numerous other cases as well. Very often, activist or nationalist leaders put moral pressure on historians to recognize their individual cases as genocide. If such scholars are convinced that the case constitutes genocide, they can conduct their research without any obstacles. If they are not convinced, they might have problems getting access to archives or testimonies. Scholars might also be blamed by survivors who absolutely want their suffering to be recognized as genocide. In sum, keeping distance from memory issues and political pressures is a very difficult task in the field of genocide research. This does not mean that scholarly works inspired by memorial issues are necessarily biased and controversial. On the contrary, some such works can constitute some of the best research, especially when they are focused on what are referred to as "forgotten genocides," which have been studied less. ${ }^{4}$ At the $O E M V$ we require each contributor writing up a case study to distinguish between "memory issues" and "interpretation of facts."

Urging humanitarian action. This occurs when non-governmental organizations (NGOs) report that a population is in danger of genocide. In such cases, using the word "genocide" aims to prompt public concern that will lead to an international intervention. This can also lead to an overuse of the word to convince state decision makers of the desperate nature of a crisis and/or to act decisively. That, of course, can be counterproductive. Indeed, if genocide is already underway in a particular country, state decision makers can reply that there is nothing that can be done because it is too late. Thus, instead of spurring action, the use of the word genocide leads to no action at all, to passivity. For this reason US legal expert David Scheffer has recommended the use of the term "mass atrocities" instead of "genocide" in cases when NGOs want to convince the international community to take action. Paradoxically, this expression is less frightening than the "G" word, which is why some academic programs are now titled Genocide and Mass Atrocities Studies. It should be kept in mind that this approach to the concept of 
mass atrocity is a practical step to maneuver through the political realities that are obstacles to human rights intervention against mass violence, not a genuine conceptual shift.

Legal purposes. When prosecuting instigators and perpetrators, such as Pinochet or Milošević, for the crime of genocide, prosecutors and judges use the wording of the UNCG, by which the International Criminal Court (ICC) abides. But it is not certain that use of the charge of genocide for prosecution is appropriate in all cases. Darfur is a good example of this: for some analysts and organizations it was a real case of genocide but for others (such as the French NGO Médecins Sans Frontières) it was not. However, this position did not prevent those concerned about the mass violence in Darfur from being deeply engaged in trying to help the people of Darfur. ICC President Luis MorenoOcampo's decision to prosecute Omar al-Bashir, the president of Sudan, for genocide has surprised those who believe that Khartoum was more responsible for ethnic cleansing, which can be qualified more as a crime of war or crime against humanity (as the legal expert Antonio Cassese argued in his report for the UN), than genocide. In that regard, one can argue that the ICC might contribute to the banalization of the word genocide.

Last but not least, the term can also be used as a moral and psychological weapon against one's enemy. For example, the Serbs of Kosovo claimed to be the victims of a new genocide by the Albanians since the middle of the 1980s, while delegates of the Conference of Durban in 2001 accused Israel of perpetrating a "real" genocide against the Palestinian people. As a result, the word is sometimes used as a symbolic shield to construct the identity of the victim, just as a sword is drawn against an enemy.

Can we hope for some clarifications from the research community? Not really. The range of definitions is very wide, from Israel Charny who thinks that any massacre is genocide (including the nuclear accident at Chernobyl) to Steven Katz who asserts that only one genocide has been perpetrated in history: the one against the Jews. Fortunately, some Holocaust scholars, such as Omer Bartov and Yehuda Bauer, have developed a different point of view and have demonstrated that they are open to comparative analysis with other cases of genocide.

Obviously, there is no consensus among scholars about what does and what does not constitute genocide. This field of research might appear as both confused and highly subject to political and memorial controversies even if researchers are doing their best to produce a high level of scholarly work. Considering that discussion around the $\mathrm{G}$ word is endless and above all leads nowhere, some eminent colleagues such as Christian Gerlach now reject the $G$ word, advocating instead alternative expressions, such as "extremely violent society." 5

On a different but certainly related note, let me underline the fact that our academic and digital initiative, our OEMV, represents a unique effort to gather together the most important historical cases of mass human destruction while honoring their singularity, thus offering a way to compare them according to the same framework of analysis. It aims to build a strong body of knowledge beyond these controversies thanks to the fact that we are following a rigorous methodology set out in our guidelines. So far so good; none of the contributions available online have provoked any major objection.

Beyond this, is it possible to bring some clarification to this new field of research? In this regard, I wish to raise three key questions/issues.

1. What is at stake in our relationship with relevant international law (i.e., the UNCG)? We can identify at least two schools of thought among genocide scholars. 
First, there is what I call the UN school of genocide scholars. Most scholars come from this school and believe that the UNCG offers the most useable definition precisely because the scholarly community is unable to agree on a common definition of genocide. They also believe that it is legitimate to make use of the legal definition as a research category in social sciences. To some extent, they are right since this was Lemkin's position in his book. ${ }^{6} \mathrm{He}$ did not intend to dissociate the historical analysis of such bloody events from its legal incrimination. But Lemkin was an international legal expert. Does his position have to be shared by historians and political scientists?

This UN school of genocide scholars has been challenged by a new generation of scholars who want to distance the field from the UN legal definition. Essentially, they ask, To what extent is it legitimate to take an international legal norm, based on a political agreement by the international community in 1948, as an operational basis for our research in history, sociology, anthropology? To do so means that we base our genocide research on an international norm which is by definition political since the text of the UNCG is clearly the outcome of an international agreement reached by the world community of states within the post-war context.

Such a concern is why scholars of the new generation want to rely first and foremost on their discipline (i.e., history, sociology, political science, anthropology) in their genocide research. They certainly take into account the legal definition but they do not want to be bound by it.

There is another basis for using alternatives to the UN definition: the need for an interdisciplinary approach. Genocide as a phenomenon in itself is so complex that it must be examined not only from the standpoint of the historian but also from that of the psychologist, the anthropologist, and so forth. Interdisciplinary analysis is absolutely necessary if we really want to study such monstrous events in-depth. Inspired by Christopher Browning's work, this is the basic argument of my book Purify and Destroy. ${ }^{7}$

2. There is a second important difference among scholars regarding the scope of the events that they define as genocide. For numerous scholars, especially in North America and the UK, genocide and massacre mean more or less the same thing. A recent example of this is found in Martin Shaw's work. ${ }^{8}$ According to Shaw, any kind of killing of an unarmed group might be regarded as genocide, an idea that lead him to support a controversial position when he recently stated that Israel committed genocide in 1948 against the Palestinian people. Bartov strongly disagreed with him in calling this expulsion of Palestinian people a genocide. ${ }^{9}$ Ultimately, they both agreed that some form of what is now called ethnic cleansing did occur in 1948. But whereas Bartov was not willing to think of this as genocide, Shaw confidently argued that any policy meant to destroy a group, even if it is not outright murder, should be seen as genocide.

I, too, disagree with Shaw's assertion that any massacre constitutes a form of genocide. This overuse of the $\mathrm{G}$ word leads to its abuse.

Being aware of this, some scholars use the expression "genocidal massacre." But this notion is rather confusing in itself. Here, as scholars, we should distance ourselves from the G word to study "massacre" as such as an independent object of research. (A new book co-edited by Lyndall Ryan and Philip Dwyer is an important and fruitful contribution in that direction. ${ }^{10}$ ) Thus, it is legitimate to study the multicausal process, which can lead a country from massacre to genocide without pre-supposing any kind of determinism, the 
road to mass killing and genocide being circuitous. I have defended the idea that not every massacre can be considered genocide and genocide is composed of one or more massacres. In other words, we need to study the genocidal process-that is, the process moving from massacre to genocide, as suggested by Leo Kuper back in the early 1980s. Still, it should be understood that my criticism about the overuse of the word genocide does not mean that I reject the term itself. At the end of Purify and Destroy, I finally present my own definition of genocide from a social scientific point of view: "[Genocide is] a particular process of civilian destruction that is directed at the total eradication of a group, the criteria by which it is identified being determined by the perpetrator." 11

3. The notion of the crime of genocide as defined in the UNCG is not comprehensive enough to be applied to the different historical processes of mass destruction to which scholars try to stretch it to cover. Instead of modifying its contents, why not have another complementary UNCG to focus on the notion of crime against humanity? It will be very helpful in clarifying many debates on legal/social scientific definitions and enriching the legal weapons to prosecute instigators and perpetrators of such crimes. In that regard, the Crimes Against Humanity Initiative, an international initiative currently led by Leilha Sadat (Washington University of St. Louis) and supported by William Schabas and many other international lawyers, is exactly what is needed today. The results of my own work have led me in that direction as well, even if I am not a legal expert.

Let us start again with the 1948 UN definition of genocide. We all know that genocide is defined through the intent to destroy a group as a whole or in part. ${ }^{12}$ But the UN text does not specify the political goals of such intent. As a historian and political scientist, it seems important to me to draw a distinction between two processes of mass destruction:

Destroying to subjugate. The goal here is to annihilate a group partly in order to force the rest of the group into total submission. The destruction process is, by definition, partial but it is intended to have an overall impact on the rest of the group. In legal terms, I understand that this can be described as a crime against humanity.

Destroying to eradicate. Genocide aims not so much to subjugate individuals tied to a given political power but rather to eliminate a community from a more or less extensive territory controlled or coveted by a state. This process involves "cleansing" or "purifying" the area of the presence of another who is deemed undesirable and/or dangerous. For this reason, the concept of eradication seems particularly relevant since its etymology conveys the idea of severing roots or extracting from the earth-in short "uprooting" - as would be said of a harmful plant or contagious disease. In legal terms, the UN definition of genocide is closely linked to this particular process of mass destruction.

These two processes often overlap in the same historical situation. In Rwanda, for example, Hutu extremists tried to eradicate the Tutsi minority while suppressing moderate Hutu. In the former Soviet Union under Stalin, these two processes of destruction were also at work. While the general aim of the communist power was to subjugate all Soviet people, Stalin's policy was to eradicate particular groups or nations perceived as enemies of his regime. If he had ever been brought to trial, Stalin might have been prosecuted for having perpetrated both genocide and crimes against humanity.

If we look at the field of genocide research as a whole, what a mess! I hope that these comments can help bring about some clarifications, but I doubt it. Individual 
scholars have their own genocide definitions in mind to apply to their personal historical cases to which they have dedicated their lives. For these reasons, and primarily because they are dedicated to speaking in the name of the dead, scholars are generally not at all flexible or ready to make any concessions. We all know scholars who specialize in a particular sub-field and no longer speak to other specialists within the same sub-field because they strongly disagree in their respective approaches. This is one of the reasons why our OEMV has opted for the more neutral and general term "mass violence."

However, we do not reject the notion of genocide. Our "Scientific Approach" explains,

Nonetheless, the incrimination of genocide remains relevant in view of the UNCG. Undoubtedly, and in spite of its ambiguity, this document represents a fundamental contribution by international lawyers. It bears witness to the emergence of a universal conscience opposing the outrageousness of mass crimes. Indeed, the UNCG appears all the more important since social scientists have been unable to agree on a common definition of genocide. Shedding light on their different approaches is among the main objectives of the OEMV. ${ }^{13}$

With respect to my own definition of genocide, I do not pretend to convince anybody else that it is the definition to which all should adhere. This leads me to be more tolerant of what does and what does not constitute genocide. What is really at stake is understanding why and how a society can slide into mass violence and mass destruction. This is exactly what Purify and Destroy is about. But that is another story.

Jacques Semelin is Professor of Political Science at Sciences-Po Paris. He is the founder and now President of massviolence.org. Among his publications are Unarmed against Hitler (Praeger, 1994), Purify and Destroy (Columbia University Press, 2007), and Resisting Genocide, ed., (Columbia University Press, 2011).

\section{Notes}

1. Online Encyclopedia of Mass Violence, http://massviolence.org/ (accessed 9 Feb 2012).

2. Convention on the Prevention and Punishment of the Crime of Genocide, 9 December 1948, 78 U.N.T.S. 277, http://www.preventgenocide.org/law/convention/text.htm (accessed 8 Feb 2012).

3. Barbara Harff and Ted R. Gurr, “Toward Empirical Theory of Genocides and Politicides: Identification and Measurement of Cases since 1945," International Studies Quarterly 32 (1988), 269-81.

4. René Lemarchand, ed., Forgotten Genocides: Oblivion, Denial and Memory (Philadelphia: U of Pennsylvania $P, 2011)$.

5. Christian Gerlach, Extremely Violent Societies: Mass Violence in the Twentieth-Century World (Cambridge: Cambridge UP, 2010).

6. See Raphael Lemkin, "Genocide," in Axis Rule in Occupied Europe: Laws of Occupation, Analysis of Government, Proposals for Redress (Washington, DC: Carnegie, 1944), 79-95.

7. Jacques Semelin, Purify and Destroy: The Political Uses of Massacre and Genocide (New York: Columbia UP, 2007). Purify and Destroy is available now in six languages (English, German, Italian, Portuguese, Slovene, French). See also Christopher Browning, Ordinary Men: Reserve Police Battalion 101 and the Final Solution in Poland (New York: Harper Collins, 1992).

8. Martin Shaw, What is Genocide? (Cambridge: Polity, 2007).

9. See their controversy in "The Question of Genocide in Palestine, 1948: An Exchange between Martin Shaw and Omer Bartov," Journal of Genocide Research 12,3-4 (2010), 243-59.

10. Philip Dwyer and Lyndall Ryan, eds., Theatres of Violence: Revisiting the Massacre in History (New York: Berghan, 2012).

11. Semelin, Purify and Destroy, 340.

12. Convention on the Prevention and Punishment of the Crime of Genocide, Article II.

13. “Our Scientific Approach," Online Encyclopedia of Mass Violence, http://www.massviolence.org/ Our-scientific-approach (accessed 9 Feb 2012). 